University of Wollongong

Research Online

University of Wollongong in Dubai - Papers

University of Wollongong in Dubai

January 2006

\title{
Cash flow ratios as a yardstick for evaluating financial performance in
} African businesses

Leonie Jooste

University of Wollongong, ljooste@uow.edu.au

Follow this and additional works at: https://ro.uow.edu.au/dubaipapers

\section{Recommended Citation}

Jooste, Leonie: Cash flow ratios as a yardstick for evaluating financial performance in African businesses 2006, 569-576.

https://ro.uow.edu.au/dubaipapers/111

Research Online is the open access institutional repository for the University of Wollongong. For further information contact the UOW Library: research-pubs@uow.edu.au 


\title{
CASH FLOW RATIOS AS A YARDSTICK FOR EVALUATING FINANCIAL PERFORMANCE IN AFRICAN BUSINESSES
}

\author{
Ms. L. Jooste, Department of Applied Accounting, Port Elizabeth Technikon, Port \\ Elizabeth, South Africa. \\ Fax: +27 41 5049823, E-mail: ljooste@petech.ac.za
}

\begin{abstract}
With the introduction of SFAS 95 and IAS 7, the cash flow statement became an integral part of financial statements. Many authors agree on the importance of cash flow for financial analysis, but to date neither text writers nor analysts have developed a set of cash flow ratios for performance evaluation.
\end{abstract}

Giacomino and Mielke (1993) proposed operating cash flow ratios for relative performance evaluation. Ratios were calculated for companies in the United States (US) in the chemical, food and electronic industries. Three-year averages or industry norms were calculated, indicating that the potential existed to develop benchmarks for the ratios by industry.

With globalization and expansion of international trade it has become important to increase the quality of financial reporting. The emphasis on cash flow is not merely a US phenomenon. The accounting framework in South Africa (SA) also indicates that an evaluation of the ability of a company to generate cash and cash equivalents and the timing and certainty of their generation is necessary for economic decision making. Jooste (1999) calculated cash flow ratios for listed companies in SA similar to those calculated by Giacomino and Mielke (1993) in the US.

When analysing a company it is important to allow comparison on a year-to-year basis, across companies or against a norm. The aim of this paper is to compare the norms for the industries in SA with those in the US. Such a comparison may lead to a better understanding of the financial performance of South African industries in an internationally competitive market.

\section{INTRODUCTION}

With the introduction of the cash flow statement as an integral part of financial statements new information became available to be included in financial evaluation. Since SA agreed to use international standards as a basis for SA standards no comprehensive set of cash flow ratios has been developed or suggested in SA for the evaluation of the cash flow statement.

After investigation it was found that many authors agree that cash flow information is a better indicator of financial performance than traditional earnings. Largay and Stickney (1980) and Lee (1982) showed that although profits were 
increasing, W.T. Grant and Laker Airways had severe cash flow problems prior to bankruptcy.

Giacomino and Mielke (1993) investigated whether the cash flow statement can enhance the usefulness of financial information for economic decision-making. The authors proposed nine cash flow-based ratios to be used for relative performance evaluation. An empirical study was conducted using US companies for the period 1986 to 1988 in the electronics, food and chemical industries. Averages for the cash flow ratios were computed for each industry. This study also determined that the potential existed to develop benchmarks for the ratios by industry.

Jooste (1999) did a similar study in SA, using the same ratios, calculations and SA industries, for the period 1994 to 1996. This period was used as the cash flow statement become mandatory in SA in 1994.

This paper compares averages of the empirical study by Jooste (1999) in SA with that of Giacomino and Mielke (1993) on US companies. Using the information available the aim of this study was to compare companies in a developing country with those of a first world country. Although the periods differ, it may be an indication of the performance of SA companies in a global market. The comparison revealed some similarities and differences.

\section{STANDARD SETTING INTERNATIONALLY AND IN SOUTH AFRICA}

Since the early 90 s the accounting profession has experienced much pressure to increase the quality and contents of financial reporting. To lessen criticism the Financial Accounting Standards Board (FASB) embarked on intensive research into the development of a conceptual framework that could serve as a basic point of reference for policy making on specific issues. The conceptual framework was completed in 1985. The International Accounting Standards Committee (IASC) found a similar need for a framework and during July 1989 issued a document titled 'Framework for the Preparation and Presentation of Financial Statements' (Everingham, Kleynhans \& Posthumus 2003).

The ISAC completed a project aimed at harmonising accounting standards internationally, by reducing the accounting choices available to preparers and producing a comprehensive set of high quality accounting standards. SA agreed to use the international standards as the basis for new standards. This avoids duplication and has the advantage of facilitating comparability of financial statements prepared in different countries (Everingham et al. 2003).

During November 1990 the Accounting Practices Board (APB) in SA accepted the framework, AC000, for SA purposes. All SA accounting standards were based on the framework to ensure that all standards are linked to the primary 
objective of financial reporting, namely, the provision of financial information useful for economic decision-making.

In 1992 the IASC issued IAS 7, Cash flow statements, effective for financial statements beginning on or after 1 January 1994. Following its publication in 1992 as the authoritative international standard on cash flow statements, IAS 7 was accepted for SA purposes in 1996 and issued as AC 118 (SAICA 1996).

\section{PERFORMANACE EVALUATION}

Users of financial statements in SA, as in the rest of the world, evaluate the financial statements of companies to determine liquidity, leverage, asset activity, profitability and performance. SA companies are also encouraged to furnish a financial review by management on certain aspects including performance factors.

Users of financial statements use traditional balance sheet and income statement ratios for performance evaluation. Operating activities are defined in AC 118 as the principal revenue-producing activities of a company. Therefore, along with traditional ratios operating cash flow is also important when evaluating a company's performance.

Relative performance evaluation, as suggested by Giacomino and Mielke (1993), proceeds from the assumption that with the comparison of a company's performance to a norm, general uncertainties are eliminated and only specific performances with regard to the company remain. The performance of other companies, or the industry then provides information regarding a specific company's performance. Cash flow information also enhances the comparability of the operation performance of a company with different companies.

According to the FASB, the primary purpose of the cash flow statement is to assess a company's liquidity, solvency, viability and financial adaptability. According to Everingham et al. (2003) operating cash flow ratios are indicators of performance. They determine the extent to which a company has generated sufficient funds:

- To repay loans;

- To maintain operating capabilities;

- To pay dividends; and

- To make new investments without using external financing.

Cash flow ratios can be used to answer questions on a company's performance since debt obligations are met with cash. Such an analysis will result in adequate lines of credit, unrestricted cash availability, debt maturity schedules with respect to financing requirements and the willingness to issue common equity. It will allow an analyst to examine a company's financial health, and how the company 
is managing its operating, investment and financing cash flows (Palepu, Healy \& Bernard 2000).

\section{THE IMPORTANCE OF CASH FLOW INFORMATION}

For more than a decade a high level of inflation has plagued SA businesses. Raising selling prices is expected to generate sufficient additional cash. However, this is not always the case. Rising costs, increased investment in working capital and the higher replacement cost of fixed assets contributes to placing more pressure on cash flows. Inflation, coupled from time to time with a recessionary climate, has resulted in management and users of financial statements focusing more closely on cash flow information than in the past (Everingham \& Hopkins 1984).

With the promulgation of the cash flow statement, a structured format was provided for deriving useful ratios to complement traditional ratio analysis. Accrual accounting does not measure cash flows. A lack of cash flow data has caused problems for investors and analysts in assessing a company's performance, liquidity, financial flexibility and operating capability (Figlewicz \& Zeller 1991).

Investigation on cash flows revealed that many authors (Carslaw \& Mills 1991) (Mills \& Yamamura 1998) (Mossman \& Bell 1998) agree on the importance of cash flow information. Cash flow may be viewed as the lifeblood of a company and the essence of its very existence (Rujoub, Cook \& Hay 1995). Zeller and Stanco (1994) report on the uniqueness and stability of operating cash flow ratios relative to accrual based financial ratios to measure a company's ability to pay.

\section{CASH FLOW RATIOS}

The concept of cash based performance ratios is not new to accounting. What is new is the availability of cash flow data. The cash flow statement offers measures to evaluate performance. If cash flow information is useful but unused, the logical conclusion is that analysts are not analyzing available data properly (Carslaw \& Mills 1991).

Many new cash flow ratios were discussed in recent professional business literature or used in financial statements in countries were the cash flow statement is mandatory. To date, no comprehensive set of cash flow ratios has been agreed upon for the evaluation of the cash flow statement. Different users may employ different financial ratios even when used for the same purpose. When different financial ratios are employed comparison of results is made unduly complex (Gombola \& Ketz 1983). 
Giacomino and Mielke (1993) proposed nine cash flow ratios to evaluate a company's performance. The cash flow ratios were used to evaluate US companies in the chemical, food and electronic industries Three-year averages were calculated for the ratios per industry. The industries were chosen as they had the largest number of companies amongst the Fortune 500. An empirical analysis was performed for the periods 1986 to 1988. All the companies in the industries were asked to provide a cash flow statement complying with SFAS 95.

Giacomino and Mielke (1993) suggested a set of cash flow ratios for relative performance evaluation using the operating activities that are the primary activities of a company as a component of each ratio. The components and interpretation of the ratios are summarised in Table 1.

Table 1: $\quad$ Summary of ratios

\begin{tabular}{|l|l|l}
\hline No. & Components of ratios & Interpretation of ratios
\end{tabular}




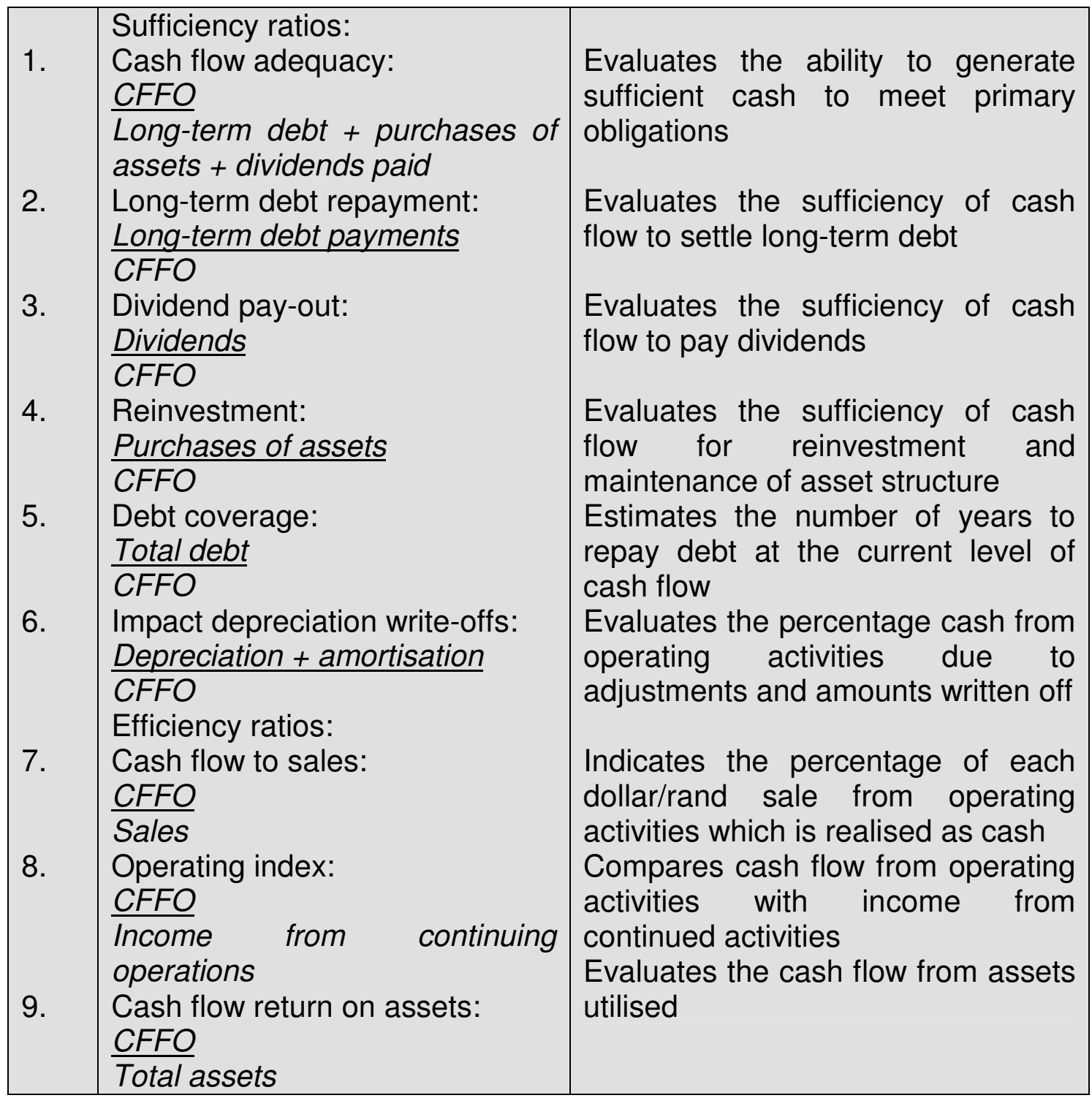

CFFO: Cash flow from operations

The ratios as set out in Table 1 are used to evaluate the sufficiency and efficiency of operating cash flows. Sufficiency means the ability of a company to provide for its cash requirements and efficiency means the extent to which cash is generated over time and relative to other companies (Giacomino and Mielke 1993).

Table 2 shows the three-year averages of the cash flow ratios calculated for US industries. The averages may be used as norms for the chemical, food and electronic industry in the US. The data was obtained from the companies in the industries.

Table 2: $\quad$ Norms for the chemical, food and electronic industries in the United States 


\begin{tabular}{|c|c|c|c|}
\hline Ratio & \multicolumn{3}{|c|}{ Three-year averages $1986-1988$} \\
\hline & Chemicals & Food & Electronics \\
\hline \multicolumn{4}{|l|}{ Sufficiency ratios } \\
\hline Cash flow adequacy & 0,88 & 0,85 & 0,89 \\
\hline Long-term debt repayment & 0,66 & 0,63 & 0,28 \\
\hline Dividend pay-outs & 0,20 & 0,18 & 0,22 \\
\hline Reinvestment & 0,63 & 0,73 & 0,85 \\
\hline Debt coverage & 5,62 & 6,06 & 6,50 \\
\hline Impact of depreciation write-offs & 0,47 & 0,63 & 0,63 \\
\hline \multicolumn{4}{|l|}{ Efficiency ratios } \\
\hline Cash flow to sales & 0,12 & 0,06 & 0,09 \\
\hline Operating index & 1,96 & 1,92 & 1,41 \\
\hline Cash flow return on assets & 0,12 & 0,11 & 0,10 \\
\hline
\end{tabular}

The three-year averages calculated in Table 2 can be used as norms against which the performance of individual companies may be compared.

Jachau and Ross (1994) did a ratio study of companies in the Australian food industry from 1992 to 1993 using the ratios suggested by Giacomino and Mielke (1993). The two-year period was chosen as it yielded the only available information since the Australian cash flow statement became effective on 30 June 1992. Jachau and Ross (1994) compared of the Australian and US food industries.

Jooste (1999) did a similar evaluation of companies in the same industries as Giacomino and Mielke (1993), for the period 1994 through to 1996. This period was chosen, as 1994 was the first year SA companies were required to include cash flow statements in financial reporting.

The norms calculated by Jooste (1999) for SA (shown in Table 3) were compared with the norms calculated for the same industries in the US. The industry ratios in SA were calculated over a three-year period 1994 to 1996. Giacomino and Mielke (1993) suggest that three-year averages may be used as norms with the potential to serve as benchmarks for the industries.

Table 3: $\quad$ Industry norms in South Africa 


\begin{tabular}{|c|c|c|c|}
\hline Ratio & \multicolumn{3}{|c|}{ Three-year averages $1994-1996$} \\
\hline & Chemicals & Food & Electronics \\
\hline \multicolumn{4}{|l|}{ Sufficiency ratios } \\
\hline Cash flow adequacy & 1,85 & 1,49 & 1,94 \\
\hline Long-term debt repayment & 0,88 & 0,60 & 0,24 \\
\hline Dividend pay-outs & 0,09 & 0,14 & 0,16 \\
\hline Reinvestment & 0,51 & 0,50 & 0,42 \\
\hline Debt coverage & 2,52 & 3,27 & 3,18 \\
\hline Impact of depreciation write-offs & 0,22 & 0,23 & 0,18 \\
\hline \multicolumn{4}{|l|}{ Efficiency ratios } \\
\hline Cash flow to sales & 0,17 & 0,09 & 0,08 \\
\hline Operating index & 0,95 & 0,89 & 0,85 \\
\hline Cash flow return on assets & 0,21 & 0,17 & 0,18 \\
\hline
\end{tabular}

Table 3 gives the averages for the ratios of the SA industries concerned. All the companies in the industries were analysed. The data on the individual companies were obtained from the Bureau for Financial Analysis (BFA) at the University of Pretoria.

\section{DATA ANALYSIS}

A comparison of the South African and the USA industries reveals some similarities and some differences. The comparison is discussed next.

\subsection{Cash flow adequacy ratio}

The cash flow adequacy ratio indicates the adequacy of a company's operating activities to generate sufficient cash to cover long-term payments, purchase of assets and payments of dividends. Giacomino and Mielke (1993) consider a ratio of one as a reasonable target. A comparison indicates that the South African industries had generated enough cash to cover their primary cash requirements whereas the USA industries did not have the capacity to fully cover the critical cash requirements.

The long-term debt payment, dividend payout and reinvestment ratios each represent a component of the cash flow adequacy ratio. When expressed as percentages and added together, the three ratios show the percentage of cash from operations available for discretionary uses.

A comparison reveals higher investment in assets and dividends payouts for SA industries. The US chemical industry had the highest long-term debt payments whereas the US food industry was slightly higher than the SA industry. The SA electronic industry, on the other hand was slightly higher than the US industry. As 
a point of interest, in both countries the electronic industry spent by far the least on long-term debt payments.

A company may use cash from investing and financing activities to pay obligations, but cash from operating activities represents the main source of longterm funds (Giacomino and Mielke 1993).

\subsection{Debt coverage ratio}

The debt coverage ratio estimates how many years, at the current level of cash from operations, it will take to retire all debt. The SA industries will take a much longer period to retire all debt than the US companies. This may account for the higher rate of investment in assets.

\subsection{Impact of depreciation write-off ratio}

The impact of the depreciation write-off ratio indicates the percentage of cash flow from operating activities that arises from adding back depreciation, adjustments and other write-offs. The norm for the SA companies seems to be much less than the USA norm. A company will be considered more efficient as well as sufficient if depreciation has a relatively low impact on cash from operations.

The reinvestment ratio should exceed the depreciation write-off ratio over several years to indicate sufficient replacement of assets at higher current costs (Giacomino \& Mielke 1993). Both countries seem to be reinvesting at a greater rate than they were depreciating assets.

\subsection{Cash flow to sales ratio}

The cash flow to sales ratio is a cash-flow-based measure of return on sales. It measures the percentage of each sales-dollar or sales-rand realized as cash from operations. The ratio for both countries is low with the chemical and food industry in South Africa higher than USA.

\subsection{Operating index ratio}

The operating index ratio compares cash from operations to income from continuing operations. It measures the cash-generating productivity of continuing operations. For each American industry the cash from operations exceeded the income from continuing operations, which is not the case for the SA industries. This ratio also indicates the extent of non-cash transactions included in operating income.

\subsection{Cash flow return on assets}


The cash flow return on asset ratio measures cash generated from assets used. All the American industries are lower than the South African industries. This ratio can also be compared with the accrual return on asset ratio.

According to Giacomino and Mielke (1993), the cash flow return on assets ratio for the electronic companies decreased from 1986 to 1988. This decrease may be due to a large increase in the reinvestment ratio.

\section{CONCLUSIONS AND RECCOMMENDATIONS}

This study compares the three-year average ratios calculated for SA industry with those calculated for US industries. Although the periods differ the same industries, ratios and calculations were used. As a point of interest, by comparing industries of a developing country with those of a first world country one may have an indication of the performance of SA companies in a global market.

Relative performance evaluation proceeds from the assumption that when a company's performance is compared with that of a norm, general uncertainties in performance will be eliminated leaving only specific company performances. Finding similar periods with similar economic conditions to use in a comparison would be ideal as it could provide new perspectives on industry performance by developing international norms for performance evaluations.

Although this paper focuses on operating activities, investing and financing activities are also important. Investing and financing activities generally support operating activities. Investing and reinvesting patterns in fixed assets is typical of a successful company as well as the financing and refinancing of debts or equities. Both debt and equity financing are required to support short and longterm operating needs (Figlewicz \& Zeller 1991).

The cash flow sufficiency ratio showed that the SA industries had enough cash to pay primary obligations whereas the USA industries did not. Furthermore, at the levels of cash generated by SA industries the investments in assets and dividend payouts were more than for US industries. The cash flow generated by assets used in South Africa is also more than that of the US but US industries retire long-term debt in shorter period than SA industries.

The work done by Giacomino and Mielke is to be recommended. Further studies on the utility of cash flow data would be necessary to develop a set of cash flowbased ratios. Such ratios used in conjunction with traditional balance sheet and income statement ratios should lead to a better understanding of the financial strengths and weaknesses of a company.

\section{REFERENCES}


Carslaw, C.A. \& Mills, J.R. 1991. Developing ratios for effective cash flow statement analysis. Journal of Accountancy, November, pp. 63-70.

Everingham, G.K. \& Hopkins, B.D. 1984. Generally accepted accounting practice - a South African viewpoint. $2^{\text {nd }}$ ed. Loose leaved service. Cape Town: Juta.

Everingham, G.K., Kleynhans, J.E. \& Posthumus, L.C. 2003. Introductory GAAP. 3re Ed. Juta: Landsdowne.

Figlewicz, R.E. \& Zeller, T.L. 1991. An analysis of performance, liquidity, coverage and capital ratios from the statement of cash flow. ABER, Vol. 22(1). Spring pp. 64-81.

Giacomino, D.E. \& Mielke, D.E. 1993. Cash flows: another approach to ratio analysis. Journal of Accountancy, March, pp. 55-58.

Gombola \& Ketz 1983, A note on cash flow and classification patterns of financial ratios, The Accounting review, Vol. LVIII (1), pp 105-114

Jooste, L. 1999. An evaluation of listed companies by means of cash flow ratios. South African Journal of Economic and Management Science, Vol. 2(1), pp. 128142.

Juchau, R. \& Ross, P. 1994. Putting cash into ratios. Australian Accountant, November, pp. 29-31.

Largay, J.A. \& Stickney, C.P. 1980. Cash flows, ratio analysis and the W.T. Grant Company bankruptcy. Financial Analysts Journal, July - August, pp. 51-54.

Lee, T.A. 1982. Laker Airways - the cash flow truth. Accountancy, June, pp. 115116.

Mills, J.R. \& Yamamura, J.H. 1998. The power of cash flow ratios. Journal of Accountancy, October, Vol. 186, Issue 4, pp. 53-60.

Mossman, C.E. \& Bell, G.G. \& Swartz, L.M. 1998. An empirical comparison of bankruptcy models. Financial Review, Vol. 33(2), pp. 35-55.

Palepu, K.G., Healy, P.M. \& Bernard, V.L. 2000. Business analysis \& valuation. Using financial statements $\left(2^{\text {nd }}\right.$ ed). City, $\mathrm{OH}$ : Thompson Learning.

Rujoub, M.A., Cook, D.M. \& Hay, L.E. 1995. Using cash flow ratios to predict business failures. Journal of Managerial Issues, Vol. 7(1), pp. 75-91.

South African Institute of Chartered Accountants (SAICA). 1996. AC 118: Cash flow statements. Johannesburg: Juta. 
Zeller, T.L. \& Stanko, B.B. 1994. Operating cash flow ratios measure a retail firm's "ability to pay". Journal of Applied Business Research, Fall, Vol. 10(4), pp. 51-60. 